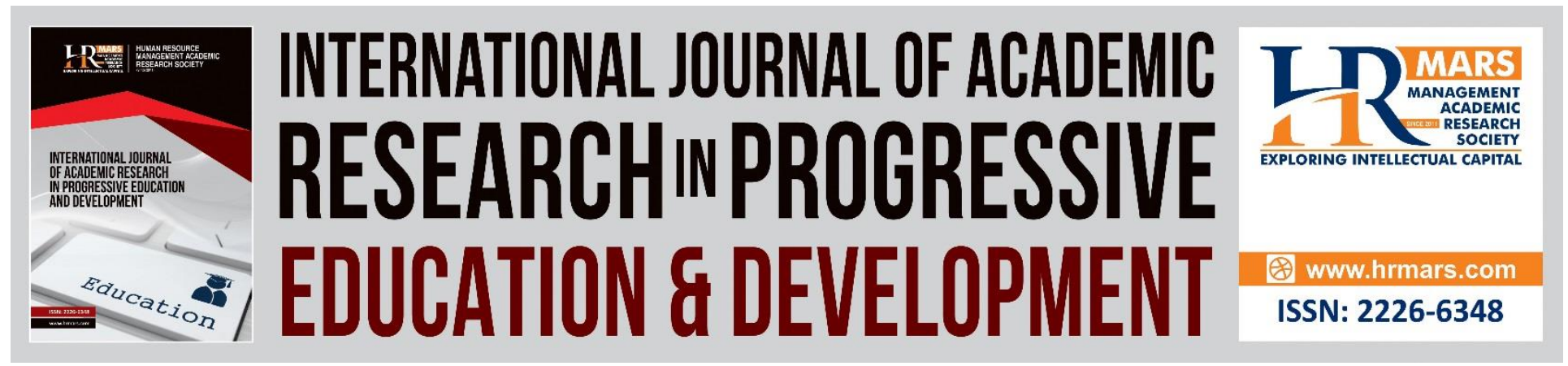

\title{
The Effectiveness of Bar Model to Enhance HOTS in Length Word Problems
}

\section{Fadzli Ali Karim, Marzita Puteh}

To Link this Article: http://dx.doi.org/10.6007/IJARPED/v10-i2/10139

DOI:10.6007/IJARPED/v10-i2/10139

Received: 08 April 2021, Revised: 06 May 2021, Accepted: 28 May 2021

Published Online: 05 June 2021

In-Text Citation: (Karim \& Puteh, 2021)

To Cite this Article: Karim, F. A., \& Puteh, M. (2021). The Effectiveness of Bar Model to Enhance HOTS in Length Word Problems. International Journal of Academic Research in Progressive Education and Development, 10(2), 570-576.

Copyright: (C) 2021 The Author(s)

Published by Human Resource Management Academic Research Society (www.hrmars.com)

This article is published under the Creative Commons Attribution (CC BY 4.0) license. Anyone may reproduce, distribute, translate and create derivative works of this article (for both commercial and non-commercial purposes), subject to full attribution to the original publication and authors. The full terms of this license may be seen at: http://creativecommons.org/licences/by/4.0/legalcode

Vol. 10(2) 2021, Pg. 570 - 576

Full Terms \& Conditions of access and use can be found at http://hrmars.com/index.php/pages/detail/publication-ethics 


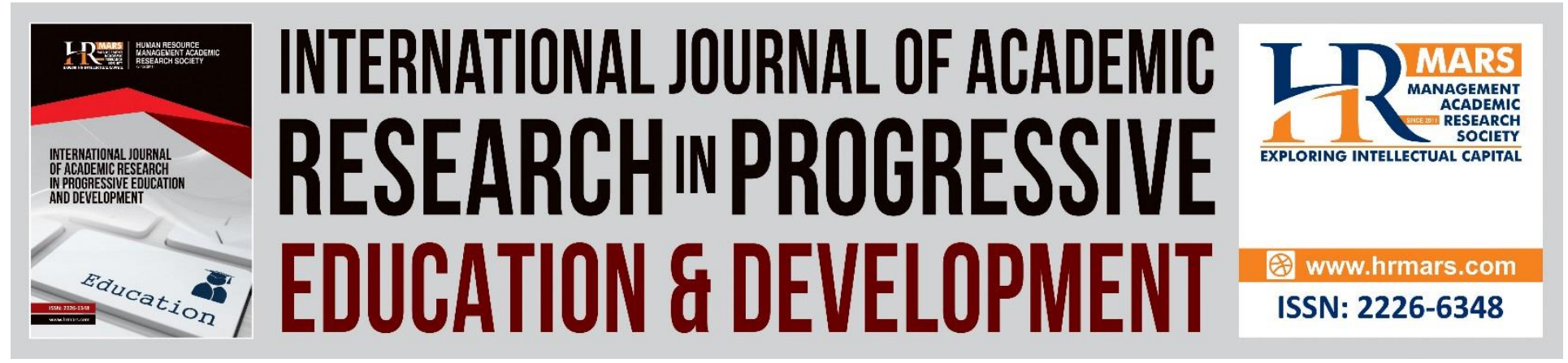

\title{
The Effectiveness of Bar Model to Enhance HOTS in Length Word Problems
}

\author{
Fadzli Ali Karim, Marzita Puteh \\ Department of Science and Mathematics, Faculty of Science and Mathematics, Universiti \\ Pendidikan Sultan Idris, 35900 Tanjong Malim, Perak, Malaysia
}

\begin{abstract}
This study aims to evaluate the effectiveness of using Bar Model in the topic Length word problem solving questions involving Higher Order Thinking Skills (HOTS). This study involved 51 Year 4 pupils from the District of Baram, Marudi, Sarawak. This study focuses to examine the effectiveness of using Bar Model by converting the HOTS problem solving questions to visual by drawing bar models. This is a quasi-experimental research and the effectiveness of this method will be analysed through the findings from pre-test and post-test. The results of this study were analysed by using SPSS version 22 for pre-test and post-test results. The results indicated that during post-test, students who used Bar Model Method showed significant improvement in their HOTS level $(p=0.000)$ compared to the control group $(p=0.435)$ which indicates that there is no difference in the pre and post-test.

Keywords: Bar Model, Higher Order Thinking Skills (HOTS), Problem Solving, Length

Introduction

Problem solving skills is one of the main focus in Mathematics. In line with one of the characteristics of student aspirations in the Malaysian Education Blueprint (MEB) 2013-2025, which emphasizes on thinking skills, problem solving can create students who are more creative and critical thinkers (Rita \& Mulia, 2016).

According to Roslina et. al (2010), problem solving skill is a complex and difficult process to learn. Students are required to incorporate all the concepts and procedures they have learned to apply in problem solving. Based on the TIMSS assessment in 2011, Abdul Halim et al. (2017) illustrate that Malaysian students are incapable of understanding facts, relationships and using them to solve word problems. Susanti et. al (2014) found that students have difficulty in solving word problems which include a) reading and interpreting data, b) defining and representing data and c) drawing conclusions.
\end{abstract}


There are several problem solving models commonly used in mathematical education such as Model Lester (1975); Mayer (1983); Polya (1973); Schoenfeld (1985). The Polya model is used in Malaysia primary mathematics curriculum. According to the Polya Model (1973), there are four phases of mathematical problem solving; (1) Understand the problem, (2) Devise a plan, (3) Carry out the plan and (4) Look Back. Unfortunately, not all students are able to solve word problems because they face difficulties in certain phases introduced by Polya (1973).

Therefore, an alternative method should be introduced to students to solve mathematics word problems. Therefore, this study was conducted to find an alternative way to help primary school students to solve word problems in the topic Length.

In Singapore, Bar Model method has been found to be effective in solving mathematical word problems. It can help to improve understanding of the problem and visualize the problem easily and subsequently solve the problem. Teaching using this method has been conducted in $86 \%$ of primary schools in Singapore (Clark, 2010). The Bar Model method used in Singapore and other western countries has been found to be very effective in teaching and learning word problems where students are asked to construct rectangular bars from given problems. There are four basic types of Singapore Bar Model which could represent the four operations, addition, subtraction, multiplication and division. 
INTERNATIONAL JOURNAL OF ACADEMIC RESEARCH IN PROGRESSIVE EDUCATION AND DEVELOPMENT

Vol. 10, No. 2, 2021, E-ISSN: 2226-6348 @ 2021 HRMARS

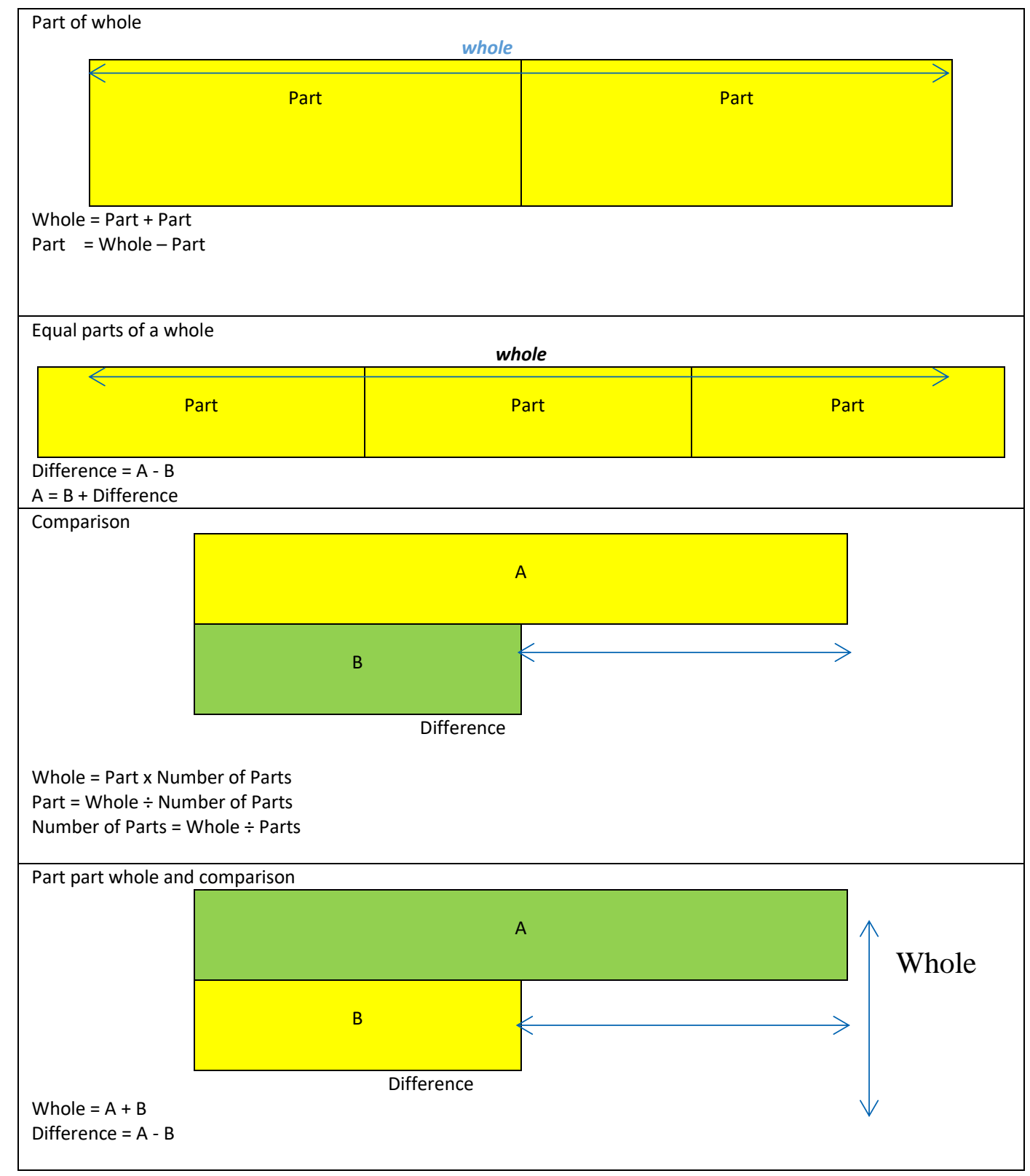

\section{Objective}

The main objective of this study is to find out the effectiveness of Bar Model Method in solving HOTS word problems in the topic Length.

\section{Methodology}

This study employed a quasi-experimental design through a quantitative approach. A total of 51 Year 4 students from a primary school in the District of Marudi, Baram, Sarawak were involved in this study. The students were divided into a control group and a treatment group. The control group $(n=26)$ uses the teaching and learning process $(T n L)$ with the conventional method, while the treatment group $(n=25)$ runs the $\mathrm{TnL}$ using the Bar Model Method. Before the TnL, both groups were given a pre-test. In the next lesson, the teacher started to teach the topic Length 
using the traditional method for the control group while for the treatment group the teacher used Bar Model Method. Eight lesson plans were provided. The teacher used the lesson plans in teaching and learning. The students from both groups sat for the post-test after the 11th week of TnL. The pre and post-test consist of the same test items. The test consists of 10 HOTS word problem questions with two subsections for each question. It covers the topic of Length Year 4. Pupils are allocated one hour to answer the questions.

\section{Results and Discussion}

\section{Mann-Whitney Test}

i. Are there any significant differences between the control group and the treatment group in the pre-test scores in solving length word problems?

To answer the research question, the researcher used the Mann-Whitney test to show the significant difference between the treatment group and the control group. For the pre-test, the $Z$ value $=-.780$ with significant level at 0.435 where $p(0.435)>\alpha(0.05)$. This result indicates that there is no significant difference between the two variables; so, the null hypothesis is accepted.

Test Statistics $^{a}$

\begin{tabular}{|l|r|}
\hline & PRETEST \\
\hline Mann-Whitney U & 284.000 \\
Wilcoxon W & 609.000 \\
Z & -.780 \\
Asymp. Sig. (2-tailed) & .435 \\
\hline
\end{tabular}

ii. Are there any significant differences between the control group and the treatment group in the post-test scores in solving length word problems?

For the post-test, $Z=-4.605$ with significant level at 0.000 where $p(0.000)<\alpha(0.05)$. This indicates that there is a significant difference between the two variables; therefore, the null hypothesis is rejected.

Test Statistics $^{\mathbf{a}}$

\begin{tabular}{|l|r|}
\hline & POSTTEST \\
\hline Mann-Whitney U & 81.500 \\
Wilcoxon W & 406.500 \\
Z & -4.605 \\
Asymp. Sig. (2-tailed) & .000 \\
\hline
\end{tabular}

\section{Wilcoxon Signed Ranks Test}

iii. Are there any significant differences between the pre and post-test scores in solving length word problems in the control group?

On the other hand, the researcher used the Wilcoxon Signed Ranks Test to compare two related samples. For the control group, $Z=-1.851$ with significant level at 0.054 where $p(0.064)>\alpha$ (0.05). This indicates that there is no significant difference before and after being taught using the conventional method. Therefore, the null hypothesis is accepted. 
Test Statistics $^{a}$

\begin{tabular}{|l|r|}
\hline & \multicolumn{1}{|c|}{ POSTTEST- } \\
& PRETEST \\
\hline$Z$ & $-1.851^{\mathrm{b}}$ \\
Asymp. Sig. (2-tailed) & .064 \\
\hline
\end{tabular}

iv. Are there any significant differences between the pre and post-test scores in solving length word problems in the treatment group?

For the treatment group, $Z=-4.472$ with significant level at 0.000 where $p(0.000)<\alpha(0.05)$. This indicates that there is a significant difference before and after being taught using the Bar Model Method. Therefore, the null hypothesis is rejected

Test Statistics $^{\text {a }}$

\begin{tabular}{|l|r|}
\hline & \multicolumn{1}{|c|}{$\begin{array}{r}\text { POSTTEST - } \\
\text { PRETEST }\end{array}$} \\
\hline$Z$ & $-4.472^{\mathrm{b}}$ \\
Asymp. Sig. (2-tailed) & .000 \\
\hline
\end{tabular}

From pre-test and post test results, the researcher found that by students able to solve word problems better by using Bar Model method. Through this study, we can make a comparison of students' mastery in solving word problems before and after using the bar model. Prior to the introduction of the intervention, respondents were unable to perform calculations, extract important information and plan strategies effectively to solve the word problems.

\section{Conclusion}

According to Piaget's theory of cognitive development, the age of 7 to 11 years is the stage of concrete operation. Therefore, students greatly need concrete materials or learning model to help them to understand the concepts and solve word problems. The use of Bar Model Method which is more in the form of visualization is able to help students to solve word problems. Bar Model is a great tool for representing and visualising relationships when solving word problems.

\section{Acknowledgement}

We would like to extend our gratitude to Ministry of Education, Malaysia and Baram District Education Office, Sarawak, Malaysia for providing the official approval that enabled us to conduct the research.

\section{Corresponding Author}

Marzita Puteh

Faculty of Science and Mathematics, Universiti Pendidikan Sultan Idris, 35900 Tanjong Malim, Perak, Malaysia.

Email: marzita@fsmt.upsi.edu.my 
INTERNATIONAL JOURNAL OF ACADEMIC RESEARCH IN PROGRESSIVE EDUCATION AND

DEVELOPMENT

Vol. 10, No. 2, 2021, E-ISSN: 2226-6348 @ 2021 HRMARS

\section{References}

Abdul Halim, A., Liyana, N. Z. A., \& Mahani, M. (2017). Using Thinking Blocks to Encourage the Use of Higher Order Thinking Skills among Students When Solving Problems . Using Thinking Blocks to Encourage the Use of Higher Order Thinking Skills among Students When Solving Problems on Fractions, 11(January), 281-287.

Clark, A. (2010). Singapore Math: A visual approach to word problems. Marshall Cavendish Education, Singapore.

Polya, G. (1973).How to Solve it: A New Aspect of Mathematical Method. New Jersey: Princeton University Pres

Rita, N., \& Mulia, P. (2016). Using task like PISA's problem to support student's creativity in mathematics. Journal of Mathematics Education, 7(1), $33-44$

Roslina, R., Subahan, T. M. M., \& Effandi, Z. (2010). Hubungan antara kepercayaan matematik, metakognisi dan perwakilan masalah dengan kejayaan penyelesaian masalah Matematik. Jurnal Pendidikan Malaysia, 35 (2), 1-7.

Susanti, E., \& Darhim, Y. S. K. J. S. (2014). Computer-Assisted Realistic Mathematics Education for Enhancing Students' Higher-Order Thinking Skills (Experimental Study in Junior High School in Palembang, Indonesia). Computer, 5(18). 